\title{
The prevalence and molecular characterisation of Cryptosporidium spp. in small ruminants in Zambia
}

\author{
F.Y. Goma ${ }^{\text {a }}$, T. Geurden ${ }^{\text {b, }}$, J. Siwila ${ }^{\text {a }}$, I.G.K. Phiri ${ }^{\text {a }}$, S. Gabriel ${ }^{\text {a,b }}$, \\ E. Claerebout ${ }^{\mathrm{b}}, \mathrm{J}$. Vercruysse ${ }^{\mathrm{b}}$ \\ a Department of Clinical Studies, School of Veterinary Medicine, University of Zambia, P.O. Box 32379, Lusaka, Zambia \\ ${ }^{\mathrm{b}}$ Laboratory of Veterinary Parasitology, Faculty of Veterinary Medicine, Ghent University, Salisburylaan 133, B-9820 Merelbeke, Belgium
}

Received 5 May 2006; received in revised form 2 August 2006; accepted 29 August 2006

Available online 27 September 2006

\begin{abstract}
Although Cryptosporidium spp. have been associated with diarrhea and mortality in sheep and goats, this is the first study to estimate the prevalence of Cryptosporidium spp. in small ruminants in Southern Africa. Between August 2003 and February 2004, a cross-sectional study with single random sampling was carried out in three Zambian provinces: Central, Southern and Lusaka province. Faecal samples from lambs and goat kids less than 3 months of age were collected and examined using the TechLab Cryptosporidium ELISA. Faecal samples of 257 animals were collected: 152 lambs on 18 farms and 105 goat kids on 13 farms. The prevalence of Cryptosporidium spp. in lambs and goat kids was $12.5 \%$ and $4.8 \%$, respectively and $30 \%$ of the sheep and goat farms had at least one positive animal at the time of the visit. A subset of the positive samples was withheld for molecular characterisation. Based on sequences obtained after amplification of the $70 \mathrm{kDa}$ heat shock protein and the Cryptosporidium 18SrRNA gene, $C$. parvum was identified in all but one of the animals. In this lamb $C$. suis was identified. The results of the present study indicate that the animal prevalence in lambs and goats kids is rather low. However, the identification of $C$. parvum illustrates that small ruminants might be potential reservoir for human infection in Zambia.
\end{abstract}

(c) 2006 Elsevier B.V. All rights reserved.

Keywords: Cryptosporidium; Sheep; Goats; Prevalence; Genotyping; Zambia

\section{Introduction}

Cryptosporidium parvum is considered one of the major gastrointestinal pathogens in young ruminants (de Graaf et al., 1999) and has been associated with diarrhea and death in both natural and experimental infections in goat kids and lambs (Angus et al., 1982; Koudela and Jiri, 1997; Johnson et al., 1999; Castro-Hermida et al., 2002). Most data on cryptosporidiosis in farm animals concern

\footnotetext{
* Corresponding author. Tel.: +32926473 93; fax: +3292647496.

E-mail address: thomas.geurden@ugent.be (T. Geurden).
}

calves and only a few cross-sectional studies have been performed to estimate the prevalence of $C$. parvum in small ruminants. In sheep prevalences between $10.1 \%$ and $68.3 \%$ have been described in young animals (Olson et al., 1997; Abd-El-Wahed, 1999; Majewska et al., 2000; Causape et al., 2002) and in goats between 11.0\% and 35.2\% (Rossanigo et al., 1987; Matos-Fernandez et al., 1993; Noordeen et al., 2000; Watanabe et al., 2005), indicating that $C$. parvum might be equally prevalent in small ruminants as in calves. Not only in ruminants, but also in man Cryptosporidium is reported on a regular basis, especially in sub-Saharan Africa. In Zambia, the prevalence of Cryptosporidium in man ranges from 18 to $32 \%$ (Conlon et al., 1990; Nchito et al., 1998; 
Amadi et al., 2001). Zoonotic transmission can occur through direct contact or through contamination of drinking water. Small ruminants are considered as a potential reservoir for human infection, although recent findings in Western Australia indicate that the public health risk of sheep-derived Cryptosporidium spp. might be overestimated (Ryan et al., 2005). In this study, the prevalence of Cryptosporidium in small ruminants on Zambian farms was estimated and a subset of the positive samples was sequenced to establish the zoonotic potential of the isolates.

\section{Materials and methods}

Between August 2003 and February 2004, a cross-sectional study on 18 randomly selected sheep farms and 13 goat farms was carried out in three Zambian provinces: Central, Southern and Lusaka province. Faecal samples from all animals less than 3 months of age at the time of the visit were collected. The samples were stored at $-20^{\circ} \mathrm{C}$ for ELISA (TechLab Cryptosporidium test, Blacksburg, Va.) and subsequent genotyping. The monoclonal antibody based ELISA was used as instructed by the manufacturer. DNA was extracted using the QIAamp ${ }^{\circledR}$ Stool Mini Kit (Qiagen) according to the manufacturer's instructions, incorporating an initial step of three freeze-thaw cycles (freezing in liquid nitrogen for $5 \mathrm{~min}$ and heating at $95^{\circ} \mathrm{C}$ for $5 \mathrm{~min}$ ) in the protocol to maximise oocyst lesion. The eluted DNA was dissolved in $15 \mu l$ ultra-pure water. Previously described nested PCR protocols for the characterisation of the HSP-70 gene (Morgan et al., 2001) and for the 18S rDNA gene (Ryan et al., 2003) were used in this study. Amplification products were subsequently visualized on $1.5 \%$ agarose gels with ethidium bromide. A positive (Plasmid DNA) and negative (PCR water) control sample was included in each PCR reaction. PCR products were purified using the Qiaquick $^{\circledR}$ purification kit (Qiagen) and fully sequenced using the Big Dye Terminator V3.1 Cycle sequencing Kit (Applied Biosystems). Sequencing reactions were analysed on a 3100 Genetic Analyzer (Applied Biosystems) and assembled with the program Seqman II (DNASTAR, Madison WI, USA). The calf prevalence is calculated as the number of animals with a positive test result on ELISA divided by the total number of animals. The farm prevalence is the number of farms with at least one positive animal at the time of the visit divided by the total number of farms. Determination of the correlation between age or faecal consistency and infection was performed using $\chi^{2}$ or Fisher's exact test. Analyses were carried out using computer software SPSS (Statistical Package for Social Sciences). Results were considered to be significant at $P<0.05$.

\section{Results and discussion}

To the authors knowledge this is the first study to estimate the prevalence of Cryptosporidium spp. in small ruminants in Southern Africa. Faecal samples of 257 ani- mals were collected: 152 lambs on 18 farms and 105 goat kids on 13 farms. The lambs (58\% male and $42 \%$ female) were Blackheaded Dorper and had a mean age of 22 (2-49) days. The goat kids (39\% male and $61 \%$ female) were African dwarf goats and had a mean age of 20 (7-56) days. There was an average number of 8.4 (1-28) lambs and 7.9 (1-17) goat kids on these farms. The number of positive lambs was 19 (prevalence $(p)=12.5 \%$ ) and the number of positive goat kids was $5(p=4.8 \%)$. Both in lambs (Olson et al., 1997; Abd-El-Wahed, 1999; Majewska et al., 2000; Causape et al., 2002) and in goat kids (Rossanigo et al., 1987; Matos-Fernandez et al., 1993; Noordeen et al., 2000; Watanabe et al., 2005) the prevalence was rather low compared to prevalence studies in other parts of the world, although both for sheep and for goats $30 \%$ of the farms had at least one positive animal at the time of the visit. In Africa similar prevalences were found in extensively reared calves (Mtambo et al., 1997; Geurden et al., 2006) altough a higher calf prevalence was described in Uganda (Nizeyi et al., 2002). The low prevalence in small ruminats might be imputed to differences in climate and husbandry system. Most sheep and goats in Zambia are managed extensively, in large outdoor paddocks or on pasture, where oocysts are dispersed on a large surface, and stocking rates are low, resulting in a low infection pressure. Furthermore, the sampling in this study took place from August to February, which includes the hot season. Exposure of infective oocysts to heat and direct sunlight (Walker et al., 2001), might reduce the oocyst viability, resulting in a reduced infection pressure and prevalence. Similar reflections were made for extensive cattle husbandry systems in Zambia (Geurden et al., 2006). The higher prevalence in small ruminants in the dry agroclimatic zone in Sri Lanka (Noordeen et al., 2000), was probably due to poor hygienic standards and nutrional stress, impairing the development of acquired immunity. In this study, there was no significant correlation between age and oocyst excretion or between faecal consistency and oocyst excretion.

Sequences were obtained for seven isolates: six from lambs, one from each positive farm and from one goat kid (Table 1). One sample did not amplify on the $18 \mathrm{~S}$ rRNA gene. In five lambs and in the goat kid sample C. parvum (genotype 2) was identified, based on a high homology ( $>96 \%$ ) with previously published sequences, both for the 18SrRNA gene (Ryan et al., 2003) and for the HSP-70 gene (Sulaiman et al., 2000; Ryan et al., 2003). In one lamb the pig genotype of $C$. parvum or Cryptosporidium suis (Ryan et al., 2004) was identified (homology $>97 \%$ ). Although there is little information on the genotypes found in sheep and goats, both $C$. 
Table 1

The results of the genotyping for sheep and one goat using the $70 \mathrm{kDa}$ heat shock protein (HSP-70) and the small subunit rRNA gene (18SrRNA)

\begin{tabular}{llll}
\hline Sample & HSP-70 & 18SrRNA & Animal \\
\hline J21 & C. parvum & C. parvum & Goat \\
J26 & C. suis & C. suis & Sheep \\
48 & C. parvum & C. parvum & Sheep \\
49 & C. parvum & C. parvum & Sheep \\
50 & C. parvum & C. parvum & Sheep \\
51 & C. parvum & C. parvum & Sheep \\
54 & C. parvum & NA & Sheep \\
\hline
\end{tabular}

One sample did not amplify (NA) on the 18SrRNA gene.

parvum (Chalmers et al., 2002) and C. suis (Ryan et al., 2005) have previously been reported in sheep. In goats only C. parvum (Chalmers et al., 2002) has been identified. Despite the low prevalence of oocysts found in lambs and goats, the identification of the zoonotic $C$. parvum in these samples indicates that sheep and possibly goats should be considered as reservoirs for human infection in Zambia, especially with the high HIV prevalence (Conlon et al., 1990) and intensive contact between animals and man. Although in contrast with findings in Western Australia where the cervid and the new bovine $\mathrm{B}$ genotype were predominantly identified and where C. parvum was not identified (Ryan et al., 2005), the genotyping results in the present study are in accordance with the genotyping results in sheep and goats in the UK where $C$. parvum was identified (Chalmers et al., 2002), indicating regional differences in the occurence of zoonotic Cryptospridium genotypes in sheep and goats.

\section{Acknowledgements}

The authors would like to thank the Flemish Inter-University Council (VLIR)-University of Zambia (UNZA) International Co-operation Project for the financial support, and Prof. S. Siziya, the technical staff of the School of Veterinary Medicine of the University of Zambia, and the farmers for their co-operation.

\section{References}

Abd-El-Wahed, M.M., 1999. Cryptosporidium infection among sheep in Qalubia Governorate, Egypt. J. Egypt. Soc. Parasitol. 29, 113-118.

Amadi, B., Kelly, P., Mwiya, M., Mulwazi, E., Sianongo, S., Changwe, F., Thomason, M., Hachungula, J., Watuka, A., Walker-Smith, J., Chintu, C., 2001. Intestinal and systemic infection HIV and mortality in Zambian children with persistent diarrhoea and malnutrition. J. Pediatr. Gastroenterol. Nutr. 32, 550-554.

Angus, K.W., Appleyard, W.T., Menzies, J.D., Campbell, I., Sherwood, D., 1982. An outbreak of diarrhoea associated with cryp- tosporidiosis in naturally reared lambs. Vet. Rec. 110, 129130.

Castro-Hermida, J.A., Gonzalez-Losada, Y., Freire-Santos, F., Gonzalez-Warleta, M., Mezo-Menendez, M., Ares-Mazas, E., 2002. Efficacy of beta-cyclodextrin against experimental cryptosporidiosis in neonatal lambs. J. Parasitol. 88, 185187.

Causape, A.C., Quilez, J., Sanchez-Acedo, C., del Cacho, E., LopezBernad, F., 2002. Prevalence and analysis of potential risk factors for Cryptosporidium parvum infection in lambs in Zaragoza (northeastern Spain). Vet. Parasitol. 104, 287-298.

Chalmers, R.M., Elwin, K., Reilly, W.J., Irvine, H., Thomas, A.L., Hunter, P.R., 2002. Cryptosporidium in farmed animals: the detection of a novel isolate in sheep. Int. J. Parasitol. 32, 2126.

Conlon, C.P., Pinching, A.J., Perera, C.U., Moody, A., Luo, N.P., Lucas, S.B., 1990. HIV related enteropathy in Zambia: a clinical, mirobiological and histological study. Am. J. Trop. Med. Hyg. $42,83-88$.

de Graaf, D.C., Vanopdenbosch, E., Ortega-Mora, L.M., Abbassi, H., Peeters, J.E., 1999. A review of the importance of cryptosporidiosis in farm animals. Int. J. Parasitol. 29, 1269-1287.

Geurden, T., Goma, F.Y., Siwila, J., Phiri, I.G.K., Mwanza, A.M., Gabriel, S., Claerebout, E., Vercruysse, J., 2006. Prevalence and genotyping of Cryptosporidium in three cattle husbandry systems in Zambia. Vet. Parasitol. 138, 217-222.

Johnson, E.H., Muirhead, D.E., Windsor, J.J., King, G.J., Al-Busaidy, R., Cornelius, R., 1999. Atypical outbreak of caprine cryptosporidiosis in the Sultanate of Oman. Vet. Rec. 145, 521-524.

Koudela, B., Jiri, V., 1997. Experimental cryptosporidiosis in kids. Vet. Parasitol. 71, 273-281.

Majewska, A.C., Werner, A., Sulima, P., Luty, T., 2000. Prevalence of Cryptosporidium in sheep and goats bred on five farms in westcentral region of Poland. Vet. Parasitol. 89, 269-275.

Matos-Fernandez, M.J., Peirera-bueno, J., Ortega-Mora, L.M., PilarIzquierdo, M., Ferre, I., Rojo-Vazquez, F.A., 1993. Prevalencia de la infeccion por Cryptosporidium parvum en corderos, cabritos y terneros en la provincial de Léon. Acta Paras. Port. 1, 211.

Morgan, U.M., Monis, P.T., Xiao, L., Limor, J., Sulaiman, I., Raidal, S., O’Donoghue, P., Gasser, R., Murray, A., Fayer, R., Blagburn, B.L., Lal, A.A., Thompson, R.C.A., 2001. Molecular and phylogenetic characterisation of Cryptosporidium from birds. Int. J. Parasitol. 31, 289-296.

Mtambo, M.M.A., Sebatwale, J.B., Kambarage, D.M., Muhairwa, A.P., Maeda, G.E., Kusiluka, L.J.M., Kazwala, R.R., 1997. Prevalence of Cryptosporidium spp. oocysts in cattle and wildlife in Morogoro region, Tanzania. Prev. Vet. Med. 31, 185-190.

Nchito, M., Kelly, P., Sianongo, S., Luo, N.P., Feldman, R., Farthing, M., Baboo, K.S., 1998. Cryptosporidosis in urban Zambian children: an analysis of risk factors. Am. J. Trop. Med. Hyg. 59, 435-437.

Nizeyi, J.B., Cranfield, M.R., Graczyk, T.K., 2002. Cattle near the Bwindi Impenetrable National Park, Uganda as a reservoir of Cryptosporidium parvum and Giardia duodenalis for local community and free-ranging gorillas. Parasitol. Res. 88, 380-385.

Noordeen, F., Rajapakse, R.P., Faizal, A.C., Horadagoda, N.U., Arulkanthan, A., 2000. Prevalence of Cryptosporidium infection in goats in selected locations in three agroclimatic zones of Sri Lanka. Vet. Parasitol. 93, 95-101.

Olson, M.E., Thorlakson, C.L., Deselliers, L., Morck, D.W., McAllister, T.A., 1997. Giardia and Cryptosporidium in Canadian farm animals. Vet. Parasitol. 68, 375-381. 
Rossanigo, E.C., Grelloni, V., Gialletti, L., Fioroni, A., Rivero, V.B., 1987. Diagnosi di criptosporidiosi in alcuni allevamenti dell' Italia Centrale. Riv. Zoot. Vet. 15, 9-15.

Ryan, U., Xiao, L., Read, C., Zhou, L., Lal, A.A., Pavlasek, I., 2003. Identification of novel Cryptosporidium genotypes from the Czech Republic. Appl. Environ. Microbiol. 69, 4302-4307.

Ryan, U.M., Monis, P., Enemark, H.L., Sulaiman, I., Samarasinghe, B., Read, C., Buddle, R., Robertson, I., Zhou, L., Thompson, R.C.A., Xiao, L., 2004. Cryptosporidium suis n. sp (Apicomplexa: cryptosporiidiae) in pigs (Sus scrofa). J. Parasitol. 90, 769-773.

Ryan, U.M., Bath, C., Robertson, I., Read, C., Elliot, A., McInnes, L., Traub, R., Besier, B., 2005. Sheep may not be an important zoonotic reservoir for Cryptosporidium and Giardia parasites. Appl. Environ. Microbiol. 71, 4992-4997.

Sulaiman, I.M., Morgan, U.M., Thompson, R.C., Lal, A.A., Xiao, L., 2000. Phylogenetic relationships of Cryptosporidium parasites based on the 70-kilodalton heat shock protein (HSP70) gene. Appl. Environ. Microbiol. 66, 2385-2391.

Walker, M., Leddy, K., Hagar, E., 2001. Effect of combined water potential and temperature stressors on Cryptosporidium parvum oocysts. Appl. Environ. Microbiol. 67, 5526-5529.

Watanabe, Y., Yang, C., Ooi, H., 2005. Cryptosporidium infection in livestock and first identification of Cryptosporidium parvum genotype in cattle feces in Taiwan. Parasitol. Res. 97, 238-241. 